\title{
DECISION-MAKING IN THE APPLICATION \\ OF AUTOMATED INFORMATION-MEASURING SYSTEMS FOR THERMAL POWER PLANTS: THE EXPERIENCE OF THE CHELYABINSK THERMAL POWER STATION-2
}

\author{
Bogatenkov S.A., ser-bogatenkov@yandex.ru, \\ Gelrud Ya.D., gelrud@mail.ru \\ South Ural State University, Chelyabinsk, Russian Federation
}

\begin{abstract}
We consider the problem of phased implementation of automated information-measuring systems at thermal power plants, economic efficiency of which is determined by their reliability, cost, volume, automated, errors of measurement, number of measuring channels, level of qualification and number of staff, as well as the impact on the performance of automated control systems and power equipment. The article formulates principles for decision-making in the application of automated information-measuring systems for thermal power plants based on the analysis of experience. In the first part of the review describes the experience of using workstations for electricity metering and registering of vibration condition of equipment and emergency situations. There are recommendations for the transition to the next stage of automation. In the second part of the review describes the experience of implementing a second stage of automation to account for the power and energy, technical diagnostics of turbine equipment and registration of emergency events. In the third part of the review we consider the problem of searching for invalid the loss of energy and technical diagnostics of measuring channels of automated information-measuring systems, as well as recommendations for the conduct of personnel policy. The recommendation is focused mainly on thermal power plants not equipped with full-scale automated control systems of technological processes.
\end{abstract}

Keywords: thermal power plant, automation, information and measuring system.

\section{Introduction}

Professional activities in power systems can be dangerous and lead to economic losses. This is due to several reasons.

First, power equipment, communication and measurement of energy flows in power systems have a great life, which leads to the need of increasing the number of energy saving measures designed to support the operation within the specified limits of reliability. Thus there is a need for frequent disconnection of individual sections of the energy flows for the planned preventative maintenance of equipment, communications and replacement of measuring devices. In addition, when performing these activities increases the time spent by staff in areas of possible electrical shock or from the action of energy or vibration, which increases the threat to its security.

Second, the measurement error of electricity and energy in the traditional setting is a value dependent on the subjective component related to the peculiarities of the staff. In addition, it is difficult to determine the economically reasonable value of peak power. Therefore, in practice, for reasons of reliability declare its inflated value.

Third, failures and damage in the measuring system can distort the commercial measurement of energy and lead to financial risk of the power supplying organizations. In addition, the errors in the measurements can be associated with the deliberate distortion of the measurements to reduce the fee for energy use by the consumer, resulting in commercial losses of energy [1].

This situation creates an energy barrier for economic growth associated with the need to raise additional funds for the implementation of energy saving measures.

Effective means for solving the above mentioned problems is the use of automated control systems of technological processes and automated information-measuring systems, including automated systems of energy accounting.

Problems requested energy-intensive industries associated with large differences in their functional, technical and cost characteristics. There are certain difficulties economically justified choice of their structure and composition in connection with the increase in the range and spectrum of these characteris- 
tics. A number of questions arise. What determines the effectiveness of the systems? How to take into account the importance of the measured value when selecting a system? In what direction, and how it is advisable to develop an automated system? How to manage operational and repair personnel of units of the automated systems and to justify economically its population given the current and future work? Where to find the reserves to reduce the number of operational and management personnel as a result of automation of computing and information works? In connection with the transition to a market economy, these issues become extremely relevant, so their solution is of great interest for business leaders and divisions.

The actual problem is the phased implementation of automated information-measuring systems at thermal power plants, economic efficiency of which is determined by their reliability, cost, volume, automated, errors of measurement, number of measuring channels, level of qualification and number of staff, as well as the impact on the performance of the automated control system and power equipment [2].

This article provides an overview of the principles for decision-making in the application of automated information-measuring systems for thermal power plants based on the analysis of experience in the Chelyabinsk thermal power station-2 (TPS-2). The principles include methods of selection, development and operation of automated information-measuring systems.

However, note that the principles have a certain orientation for various thermal power plants.

Currently, you can name dozens of plants with modern control systems of technological processes, in determining its functional area for the purpose of improving and maintaining a high level of automation of technologies of electricity production.

However, for a number of tasks requires specialized information-measuring tools:

- objectives of commercial accounting require the use of high-precision, specially certified for these tasks of measurement instrumentation;

- for tasks of vibration diagnostics required very small step discontinuity, the sensors response time measured in microseconds;

- a similar, slightly less stringent requirements: or one half-milliseconds, necessary for the purposes of the registration of emergency in parts of electrical equipment.

Marked points indicate that many of the recommendations can be without problems implemented on the basis of standard software and hardware packages, being a program is an integral part of the automated control systems of technological processes. At the same time, there are a number of problems of thermal power plant, equipped with automated control systems of technological processes, which cannot be solved without the use of automated information-measuring systems. Therefore, the principles of decision-making in the conditions of introduction of automated information-measuring systems as focused on thermal power plants not equipped with automated control systems of technological processes (mostly) and thermal power plants with automated control systems of technological processes (to a lesser extent).

\section{The principles of decision-making in the conditions of introduction}

\section{of automated information-measuring systems for thermal power plants}

The efficiency of thermal power plants is defined through the achievement of the planned indicators of electricity and energy at minimum cost.

The result of the application of automated energy metering decreases the measurement error, the magnitude of which determines the level of energy saving measures, because the payment for the energy carrier depends on the measurement error.

The vibration level of the equipment of thermal power plants is among the most important technical indicators that determine the operational reliability of turbines, pumps, smoke exhausters, fans, and mills. The increasing vibration is accompanied by substantial alternating loads on the supporting elements of the machine and may lead to their deterioration and destruction. For example, in Chelyabinsk TPS-2 is known for the case of vibration destruction pouring a Babbitt bearing at the sixth turbogenerator TG-3. Vibrations of the rotor cause an increased wear of the seals, movable elements of the clutch gearing. In addition to the negative impact on the operation of the turbine generator vibration has a negative influence on people's health, increases fatigue and reduces the attention of operating personnel Therefore, the use of automated information-measuring systems for measuring a vibration condition of the equipment of thermal power plant allows performing a vibration analysis and alert emergency.

Carrying out activities to create conditions of trouble-free operation of electric power systems are planned based on the analysis of past emergency events. Therefore, an effective tool to analyze the ope- 


\section{Управление в социально-экономических системах}

ration of power equipment, switchgear and devices of relay protection and automatics is emergency situations.

These moments are a priority to ensure the effectiveness of TES, so the automated informationmeasuring system should incorporate subsystems for metering, monitoring and logging of emergency events.

The introduction of automated working places of specialists responsible for energy accounting, monitoring of equipment and recording of emergency events is performed at the initial stage. Workstations usually operate in local mode, so the measurement results available to a narrow circle of persons.

The development of automated information-measuring systems associated with the introduction of automated systems to perform which is recommended in accordance with the principle of necessity of full automation based on the feasibility of the liberation of labour staff subject to the solvency and willingness of stakeholders. On the one hand, full automation does not lead to the possibility of reducing the personnel of the enterprises with a relatively small number of measuring channels, i.e. when we have one person, and with another - it should not be used if the user does not aim at reducing the number of staff or may not Fund the implementation of.

A preliminary comparative evaluation of automated information-measuring system at the stage of a feasibility study in relation to actual conditions can be made using the principle of selection grade of automation for the importance of channels. Full automation is carried out on important channels, and partial for the rest. For example, the Chelyabinsk thermal power station-2 for vibration diagnostics of bearings of turbines used by the automatic system, and to control the vibration of the pumps and boiler equipment - automated.

The effectiveness of decision-making depends on rapid provision of results of measurements a wide range of people, so it makes sense to move on to the introduction of automatic measuring instruments. When you use workstations in conjunction with automatic tools, it is advisable to use a local area network (Fig. 1).

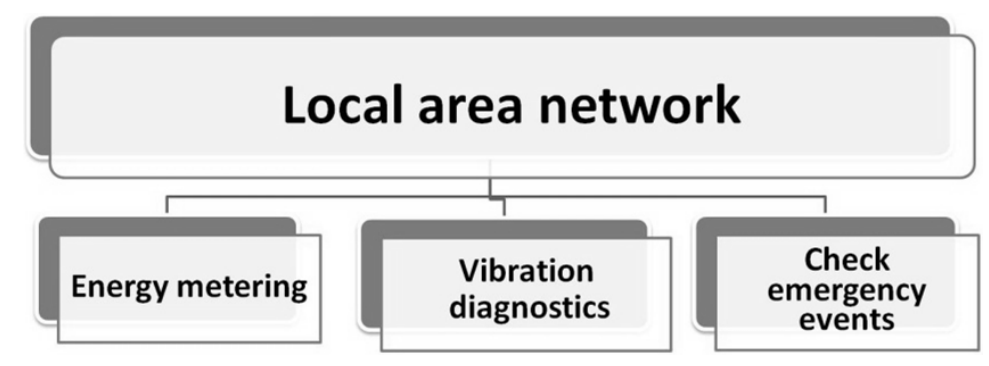

Fig. 1. The composition of automated information-measuring system

To reduce the time and improve the efficiency of the implementation of the automated system recommended in the personnel policy to comply with the principle of reasonable centralization and comprehensive involvement of highly qualified personnel, able in a short time to get effective results for implementation of automated systems and to conduct qualified training of operational and maintenance personnel.

Describes the features and implementation of automated information-measuring systems have found their use at the Chelyabinsk TPS-2.

\section{The use of workstations}

The operation of automated accounting systems of energy, ranging from small software to large industrial complexes, includes the steps of input, processing, transmission of the measured parameters into a computer and performing calculations. At each stage of automation reduces the measurement error, the magnitude of which determines the level of energy saving measures, because the payment for the energy carrier depends on the measurement error.

In traditional accounting, the energy measurement error is defined as an objective factor related to the precision of measurement, and subjective, depending on the personnel action. In electricity metering subjective component of error depends on the time of bypass and the correctness of the record of meter readings. When accounting for the energy of this component depends on the accuracy of processing chart. 
The result of the use of workstations for accounting of the coolant flow rate error of computation can be reduced by 1-2\% due to the effect of a number of factors. For example, when calculating gas flow is often not taken into account the effects of changes in density and composition of the gas and barometric pressure. In addition, the same amount can be reduced error handling chart scanner digitizer replacement planimeter or.

For vibration diagnostics of pumps and boiler equipment (mills, exhausters, blowers) at the Chelyabinsk TPS-2 used automated workplace of the engineer in vibration. Its software is intended for use in the system of the projected equipment and provides the maximum automation of processes for routine checks of the equipment, entering data into the database, their analysis, developing the necessary protocols and reporting materials. The basis of preventive examinations is to conduct periodic examinations of objects and collection of data at the measuring points. A guide for data collection is formed by the form of route surveys.

The application of automated workplace of the expert on registration of emergency situations allows you to perform the emergency oscillography of transient processes in power equipment and recording the status and sequence of operation of switching equipment and devices of relay protection and automation. In the basic version of the system used at the Chelyabinsk TPS-2 recorded 48192 analog and a discrete signal.

Thus, examples of application of the automated workplaces for energy accounting, monitoring of equipment and registration of emergency situations in the Chelyabinsk TPS-2.

\section{The development of automated information-measuring systems}

Full automation of the measuring channels allows to reduce error, increase efficiency of the information and to find reserves to reduce the number of personnel associated with the collection, processing and transmission of measured data.

Widespread in enterprises of industry and energy has received a complex of technical means "Energy", intended for building automated information-measuring systems of commercial and technical accounting of all types of energy - electric and heat energy, natural and technical gases, steam, hot and cold water. Website developer and manufacturer of complex of technical means "Energy" given more than 1,000 such companies [3].

In the traditional accounting system is difficult to calculate economically substantiated the claimed peak power, so for reliability it is usually overpriced, otherwise, when it is actually the excess you have to pay heavy fines.

Automated systems of commercial and technical accounting of energy for all types of energy allow the company:

- to control the conformity of the actual and allowable off-balance sheet activities of electricity consumption by substation, and the company;

- quickly control the load level of electrical power;

- to choose and, if necessary, to change the normal scheme of power supply enterprises to minimize energy losses;

- identify sources of non-normative losses of electricity within the structural units and in electricity transmission;

- quickly to control reactive power, to develop measures to reduce it in order to reduce process losses, reducing the load of power equipment, increase turnaround time;

- to set limits (hourly, daily, monthly) energy consumption for the structural units and monitor their execution;

- to obtain operational control over the reliability of commercial accounting of energy resources;

- to make the control over the observance of the norms of specific energy consumption in the production process, given the production volume and quality;

- to analyze the efficiency of energy use;

- information to provide and monitor the implementation of energy conservation measures;

- to conduct an analysis to identify cases of inefficient use of energy resources and their causes.

At the Chelyabinsk TPS-2 complex of technical means "Energy" used for commercial calculations:

- leave the consumers of electricity, steam, water network;

- for station consumption of natural gas, drinking and industrial water. 


\section{Управление в социально-экономических системах}

In addition, the complex processes data received from electricity meters, through the main scheme and sections $6 \mathrm{kV}$, servicing of boiler and turbine equipment, and also data on energy, participating in the commercial accounting. The system has 310 channels of information (including 210 - metering of electricity and 50 in the account of energy carriers) and 25 devices for data collection, including an $18-$ metering and 7 - accounting of energy.

Thanks to a flexible software complex of technical means "Energy" created the required groups of channels into account, is developed a convenient output forms that reflect the needs of users. So, the balance of electrical energy in the main scheme for the month is calculated automatically and is transferred to the power company via e-mail. As a result of automation of data collection, the unbalance of the electric power decreased 10 times, become unnecessary logging of meter readings, the calculation of the imbalance and filling the output forms. Developed output forms for watches of electricity metering, which allow to evaluate the performance of each specific watch for the generation of electricity, its costs for own needs, including specifically for different types of boiler and turbine equipment. In addition, a series of documents allowing to determine the time of operation of the boiler and turbine equipment. That data can be used to automatically generate graphs of the actual operation of the equipment and to calculate the real technical and economic indicators of station operation. Introduction of a complex of technical means "Energy" at the Chelyabinsk TPS-2 has allowed to reduce the declared peak power by $10 \%[3]$.

At the Chelyabinsk TPS-2 introduced a complex of technical diagnostics of turbine equipment. Input technological information complex are the current values of analog parameters received from optional sensors installed, the system of collecting and processing of information, frequency $5 . . .60$ seconds. Further information is provided on the remote units, and with them on the file server local area network. Information about vibratory equipment status available from any workstation local area network. Users on the local network are given information in the form of statements, tables, graphs and diagrams, divided into categories.

Scalar vibration characteristics of bearings, such as the vertical, transverse and axial components of the mean square average values. Information contains the technological parameters of the object of diagnosis in the pace of the process. Observed normal, satisfactory and unsatisfactory levels of vibration.

Computed information: oscillations in the rotors of high, medium and low pressure in the rotor of the generator, as well as distortions and crankshaft.

Qualitative information takes the values: normal, satisfactory, and unsatisfactory.

The output generated by the solution of problems of technical diagnostics, the analysis of the situation and defines the possible actions of operational and maintenance personnel.

The introduction of an automated vibration diagnostics at the Chelyabinsk TPS-2 will effectively perform activities to ensure acceptable vibration levels.

Automatic system for registration of emergency situations allows to register several hundred analog signals as a result of modernization of technical equipment and improvement of software. On the one hand, is the acquisition and Association of the units of micro-PC in the local network, and the other is the addition of the start system of the oscilloscope voltage negative sequence. If this named parameter is defined programmatically and does not require external hardware. Similarly, parameters are calculated $3 \mathrm{U} 0$ and 3I0. Software implementation of these launchers bodies releases $25 \%$ of the analog inputs that you can use to increase the number of controlled points.

The connection of the system to a local area network mimic objects and forms of switches will be available to any user on the network. In addition, it will be possible to connect the test system for relay protection, able to generate real electrical parameters, on the basis of recorded in a computer server, waveforms and alarm events.

\section{Operation of automated information-measuring systems}

Personnel policy. The effectiveness of the implementation of automated systems is largely determined by the skill level, size and organizational structure of the governing, operating and maintenance personnel. For example, enterprises Chelyabenergo, it was decided to implement a complex of technical means "Energy", and the corresponding order on each company took several people to address the task of implementing, and at some enterprises they went into production and technical Department, on the other - to the shop of thermal automatics and measurements. At Chelyabinsk TPS-2 in part of the shop 
of thermal automation and measurements was established the station of automated control systems. Its organizers are people with great production and research experience, $\mathrm{PhD}$ candidates: the former chief of shop of thermal automatics and measurement specialist at flow-measuring devices, and engineermathematician. Programmers solved the problem by setting up a comprehensive information-measuring system. To work with the complex of technical means "Energy" was adopted and trained five duty engineers. After introduction of the system of technical diagnostics of turbine equipment or the Registrar of emergency events, their operation also became operational personnel.

As a result of introduction of automated information-measuring systems have the ability to use the results in decision support systems guiding decisions (Fig. 2) and operative (Fig. 3) staff of station.

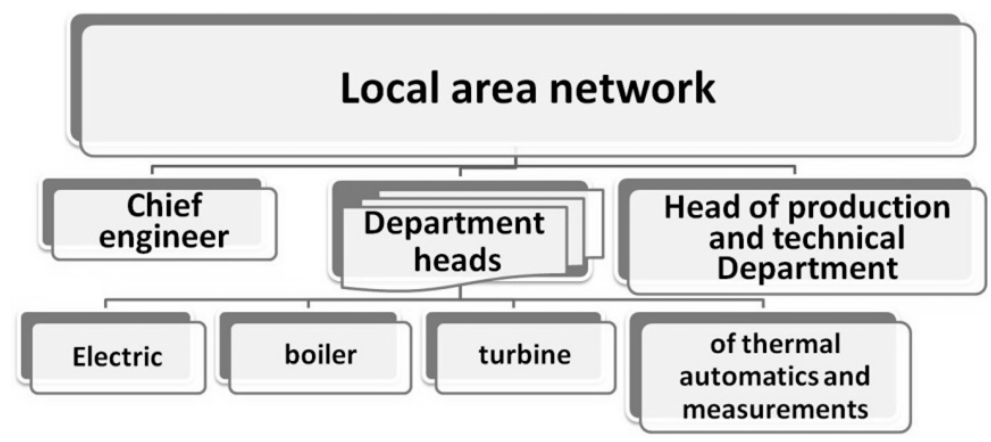

Fig. 2. System of decision support for senior staff

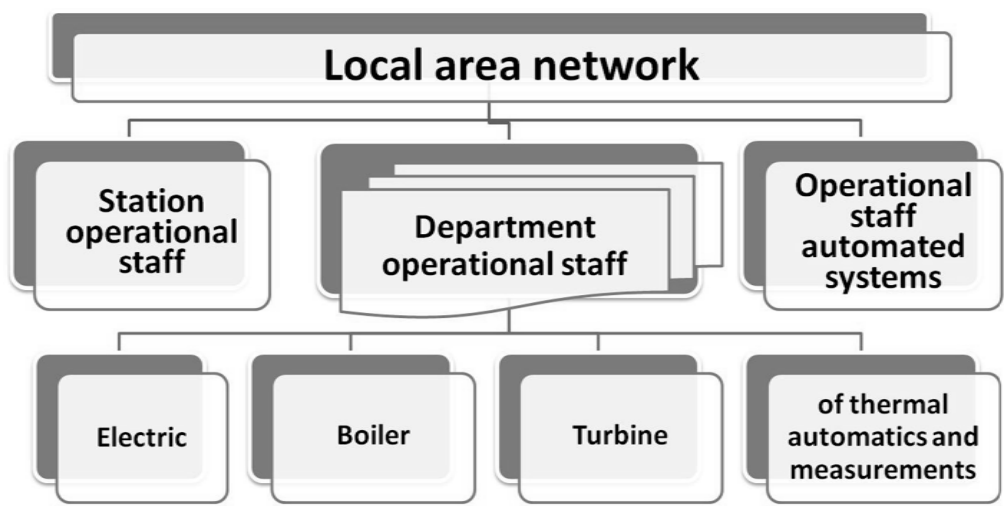

Fig. 3. System of decision support for operational staff

Given the urgency of finding invalid loss of energy and technical diagnostics of measuring channels, consider the technology decision-making in the tasks of data using automated systems.

Traditionally, the process of finding invalid loss of energy and technical diagnostics of measuring channels is performed according to the approved schedule, and are associated with prolonged stay of personnel in the areas of possible destruction from the action of electricity or energy. Therefore, to ensure safe operation it is advisable to minimize the time spent by personnel in hazardous areas.

Consider how you would solve these problems using the automated system of decision support.

Search unacceptable energy losses with the help of technical means "Energy". Account generation and energy consumption in real time allows localizing the areas with unacceptable energy losses and thereby reducing the time and complexity of the search process. Using the software of the automated system, you can create groups of channels to account the energy balances defining the power circuits and periodically analyze them. If the value is within the permissible limits of balance, we can conclude about the possible leakage of energy in this path and to carry out measures to find the cause.

In the article [4] describes the experience of finding invalid energy loss by using the complex of technical means "Energy" on commercial accounting of energy at the Chelyabinsk TPS-2.The analysis of commercial flows of energy created by channel group of metering gas, steam and hot water that determine the balance of these energy contours. At Chelyabinsk TPS-2 the site was created for engineers automated control systems that perform around the clock, whose duties included periodic monitoring of 


\section{Управление в социально-экономических системах}

indicators of the balance of power circuits. If the value of balance beyond acceptable limits the software of the automated system was formed by a signal corresponding to the duty engineer. Upon receipt of such a signal, the duty engineer proceeded to the analysis of time measuring channels included in the critical balance circuit. The result of this analysis is the minimum area with unacceptable energy losses. In the next stage, the duty engineer was at a critical phase, identify the cause of the imbalance and set about its removal. In case of any problems, the duty engineer spoke to a specialist repair division, which provided assistance to eliminate the causes of imbalance.

Technical diagnostics of measuring channels using the complex of technical means "Energy". Implementation of automated energy metering allows you to identify individual cases of incorrect behavior of the measuring channels for the analysis of the readings from the monitor screen. For example, "creep" meter with broken equipment or absence of meter readings during the operation of equipment.

Output of the automated system can identify the channels which had ceased impulses. So identify the open circuit and idle counters. Based on the observations half-hour packages during the week you can analyze the work history of the failed device data collection.

A particular challenge is the task of identifying the measuring channel is invalids the systematic error of the meter or the device forming pulses. Traditionally, these measurement channels detected by periodic monitoring of all meters and devices of the pulse-forming with the use of exemplary devices in two stages. First validates the values of the counters the system values of the counters in the complex of technical means "Energy" (identification errors of the device forming pulses). It then parses the output records half-hour capacity of each measuring channel, i.e. check each counter included in the carrying contour.

When a large number of channels in the financial circuit the procedure for the identification of unreliable channel is labor intensive and time consuming. To reduce the complexity and reducing the time of operation verification of the measuring channels with the employees of Chelyabinsk TPS-2, the method and computer program technical diagnostics of measuring channels.

Using the software complex of technical means "Energy" using the apparatus for forming groups based on the analysis of schemes of streams of electricity at the Chelyabinsk TPS- 2 was determined by the balance group.

For the balance of the circuits, the balances of which are outside the specified limits are analyzed graphs of average daily capacity of channels and graphs of average thirty-capacities of the channels with minimum and maximum values of the unbalance. Named graphs are considered in descending order of numbers of the day, because, on the one hand, systematic error of the measuring channel has a gradual monotonically increasing effect on the value of unbalance, on the other hand, can be a different switch in the wiring diagram or disable measurement channels associated with the process. The consideration of these factors in the analysis of the graph allows to effectively eliminating the channels that have a weak influence on the increase of unbalance.

The use of methods of technical diagnostics and possibilities of technical means "Energy" allows solving the problem of finding inaccurate measurement channels, not being in the area of possible electric shock.

The use of methods of search of unacceptable losses of energy and technical diagnostics of measuring channels using the complex of technical means "Energy" allows to solve these tasks, not being in threat zones. However, it sets higher requirements for qualification of personnel, because on the one hand, he must know the peculiarities of the technological process, on the other hand, must be skilled user of technical means complex "Energy". In addition, the process of solving these problems takes a lot of time in connection with its performance under conditions of uncertainty and risk [5].

Effective approach to solving problems under conditions of uncertainty and risk is the analysis of processes based on simulation methods, for example, in the simulation of processes of functioning of stakeholders [6] or the analysis of socio-economic systems by the method of the eigenstates [7]. Known mathematical method of monitoring the reliability of the measuring information about the flow of energy resources on the basis of the theory of state estimation, which enables to assess the level of commercial losses and to localize them [1] and the method of monitoring compliance with operational requirements as a result of constructing models of the safe condition of the power system [8]. 


\section{Conclusion}

The principles of decision-making in the application of automated information-measuring systems in thermal power plants are formulated on the basis of analysis of experience.

First, to ensure the efficiency of thermal power plants automated information-measuring system should include priority areas for automation, such as energy metering, monitoring and recording of emergency events.

Second, the need for full automation should be based on the feasibility of the liberation of labor staff subject to the solvency and willingness of stakeholders.

Third, full automation is advantageously carried out on important channels, and partial for the rest.

Fourth, in the personnel policy it is recommended to follow the principle of reasonable centralization and comprehensive involvement of highly qualified personnel, able in a short time to get effective results for implementation of automated systems and to conduct qualified training of operational and maintenance personnel.

The recommendation is focused mainly on thermal power plants not equipped with full-scale automated control systems of technological processes.

\section{References}

1. Pazderin A.V., Sofin V.V., Samoylenko V.O. [Mathematical Method of Monitoring the Reliability of the Measuring Information about the Flow of Energy Resources on the Basis of the Theory of State Estimation]. Heat Power Engineering, 2015, no. 11, pp. 26-31. (in Russ.)

2. Koreckiy A.S., Rincus E.K., Oster-Miller Yu.R. Effektivnost' avtomatizirovannykh system upravleniya teploenergeticheskimi protsessami [Effectiveness of Automated Control Systems of Heat Power Processes]. Moscow, Energoatomizdat, 1984. 316 p.

3. Website of the Company "Energocontrol"'. Available at: http://www.energocontrol.ru.

4. Bogatenkov S.A. [Models, Methods and Means of Information Support of Decision-Making in Educational Information Systems]. Proceedings of the Scientific-Methodical International Conference "Informatization of Engineering Education" - INFORINO-2014. Moscow, Publishing House of MEI, 2014, pp. 31-34. (in Russ.)

5. Bogatenkov S.A. [The Use of Automated Information-measuring Systems in the Tasks of Finding Invalid Loss of Energy and Technical Diagnostics of Measuring Channels]. Trudy Mezhdunarodnoy nauchno-metodicheskoy konefentsii "Informatizatsiya inzhenernogo obrazovaniya" [Proc. of the Scientific-Methodical International Conference "Informatization of Engineering Education" INFORINO-2016]. Moscow, Publ. House of MEI, 2016, pp. 276-279. (in Russ.)

6. Gelrud Ya.D., Loginovskiy O.V. Upravlenie proektami: metody, modeli, sistemy: monografiya [Project Management: Methods, Models, Systems: Monograph]. South Ural St. Univ. Publ. Center, 2015. $330 \mathrm{p}$.

7. Mokeyev V.V., Vorobiev D.A. Analysis of Socio-Economic System Processes Performance with the Help of Eigenstate Models. Bulletin of the South Ural State University. Ser. Mathematical Modeling and Programming, 2015, vol. 8, no. 1, pp. 66-75. DOI: 10.14529/mmp150105

8. Bogatenkov S.A., Malovechko S.N., Kosterin V.V. Secure State Power System Models Building. 2nd International Conference on Industrial Engineering, Applications and Manufacturing (ICIEAM). Moscow, IEE, 2016, pp. 276-279.

Received 13 November 2016 


\title{
ПРИНЯТИЕ РЕШЕНИЙ В УСЛОВИЯХ ПРИМЕНЕНИЯ АВТОМАТИЗИРОВАННЫХ ИНФОРМАЦИОННО-ИЗМЕРИТЕЛЬНЫХ СИСТЕМ НА ТЭС: ОПЫТ ЧЕЛЯБИНСКОЙ ТЭЦ-2
}

\author{
С.А. Богатенков, Я.Д. Гельруд \\ Южно-Уральский государственный университет, г. Челябинск
}

\begin{abstract}
Рассматривается задача поэтапного внедрения автоматизированных информационноизмерительных систем на ТЭС, экономическая эффективность которого определяется их надежностью, стоимостью, объемом автоматизируемых работ, погрешностями измерений, числом измерительных каналов, уровнем квалификации и количеством персонала, а также влиянием на показатели качества работы автоматизированных систем управления и теплоэнергетического оборудования. В статье сформулированы принципы для принятия решений в условиях применения автоматизированных информационно-измерительных систем на ТЭС на основе анализа опыта работы. В первой части обзора рассмотрен опыт применения автоматизированных рабочих мест для учета энергоносителей и регистрации вибрационного состояния оборудования и аварийных ситуаций. Даны рекомендации для перехода к следующему этапу автоматизации. Во второй части обзора описан опыт внедрения второго этапа автоматизации для учета электроэнергии и энергоносителей, технической диагностики турбинного оборудования и регистрации аварийных событий. В третьей части обзора рассмотрены задачи поиска недопустимых потерь энергии и технической диагностикой измерительных каналов с помощью автоматизированных информационно-измерительных систем, а также даны рекомендации по ведению кадровой политики. Рекомендации статьи ориентированы, в основном, на ТЭС, не оснащенные полномасштабными автоматизированными системами управления технологическими процессами.
\end{abstract}

Ключевые слова: тепловые электростанции, автоматизаџия, информационно-измерительные системы.

\section{Лuтература}

1. Паздерин, А.В. Математический метод контроля достоверности измерительной информации о потоках энергетических ресурсов на основе теории оиенивания состояния / А.В. Паздерин, В.В. Софьин, В.О. Самойленко // Теплоэнергетика. - 2015. - № 11. - С. 26-31.

2. Эффективность АСУ теплоэнергетическими проиессами / А.С. Кореикий, Э.К. Ринкус, Ю.Р. Остер-Миллер и др.; под ред. А.С. Кореикого и Э.К. Ринкуса. - М.: Энергоатомиздат, 1984.

3. Сайт фирмы ООО НТП «Энергоконтроль». - http://www.energocontrol.ru.

4. Богатенков, С.А. Модели, методы и средства информационной поддержки принятия решений в системе информачионной подготовки кадров / С.А. Богатенков // Труды Международной научно-методической конференции «Информатизачия инженерного образования» ИНФОРИНО-2014. - М.: Изд-во МЭИ, 2014. - С. 31-34.

5. Богатенков, С.А. Применение автоматизированных информационно-измерительных систем в задачах поиска недопустимых потерь энергии и технической диагностики измерительных каналов / С.А. Богатенков // Труды Международной научно-методической конференции «Информатизация инженерного образования» - ИНФОРИНО-2016. - М.: Изд-во МЭИ, 2016. C. 276-279.

6. Гельруд, Я.Д. Управление проектами: методы, модели, системы: моногр. / Я.Д. Гельруд, О.В. Логиновский; под ред. д-ра техн. наук, проф. А.Л. Шестакова. - Челябинск: Издат. иентр ЮУрГУ, 2015. - 330 c.

7. Mokeyev, V.V. Analysis of Socio-Economic System Processes Performance with the Help of Eigenstate Models / V.V. Mokeyev, D.A. Vorobiev // Вестник ЮУрГУ. Серия «Математическое моделирование и программирование». - 2015. - T. 8, № 1. - C. 66-75. DOI: 10.14529/mmp150105 
8. Bogatenkov, S.A. Secure State Power System Models Building / S.A. Bogatenkov, S.N. Malovechko, V.V. Kosterin // 2nd International Conference on Industrial Engineering, Applications and Manufacturing (ICIEAM). - M.: IEE, 2016. - P. 276-279.

Богатенков Сергей Александрович, канд. техн. наук, доцент кафедры информационных технологий в экономике, Южно-Уральский государственный университет, г. Челябинск; ser-bogatenkov@, yandex.ru.

Гельруд Яков Давидович, д-р техн. наук, профессор кафедры информационно-аналитического обеспечения управления в социальных и экономических системах, Южно-Уральский государственный университет, г. Челябинск; gelrud@mail.ru.

Поступила в редакцию 13 ноября 2016 2.

\section{ОБРАЗЕЦ ЦИТИРОВАНИЯ}

Bogatenkov, S.A. Decision-Making in the Application of Automated Information-Measuring Systems for Thermal Power Plants: the Experience of the Chelyabinsk Thermal Power Station-2 / S.A. Bogatenkov, Ya.D. Gelrud // Вестник ЮУрГУ. Серия «Компьютерные технологии, управление, радиоэлектроника». - 2017. - Т. 17, № 1. C. $74-83$. DOI: $10.14529 /$ ctcr 170108

\section{FOR CITATION}

Bogatenkov S.A., Gelrud Ya.D. Decision-Making in the Application of Automated Information-Measuring Systems for Thermal Power Plants: the Experience of the Chelyabinsk Thermal Power Station-2. Bulletin of the South Ural State University. Ser. Computer Technologies, Automatic Control, Radio Electronics, 2017, vol. 17, no. 1, pp. 74-83. DOI: 10.14529/ctcr170108 